Schulich School of Law, Dalhousie University

Schulich Law Scholars

2017

Protecting Urban Spaces of Intangible Cultural Heritage and Nighttime Community Subcultural Wealth: A Comparison of International and National Strategies, The Agent of Change Principle, and Creative Placekeeping

Sara Gwendolyn Ross

Follow this and additional works at: https://digitalcommons.schulichlaw.dal.ca/scholarly_works

Part of the Law and Society Commons, and the Property Law and Real Estate Commons 


\title{
Protecting Urban Spaces of Intangible Cultural Heritage and Nighttime Community Subcultural Wealth: A Comparison of International and National Strategies, The Agent of Change Principle, and Creative Placekeeping
}

\begin{abstract}
Working towards an equality of differences of a city's diverse cultures and subcultures requires an examination of the realities of how municipal and provincial legal frameworks governing the city space-such as urban planning policies, zoning decisions, and bylaw enforcement-play out within the microcosm of the everyday neighborhood, where conflicting life patterns must coexist even when they are at odds. Drawing on an urban legal anthropology and urban legal geography methodology assessing the realities of the life of subcultural communities in the city space, this paper's objective is to explore potential paths towards an equitable regard and valuation of the different ways of knowing and being in the context of city redevelopment and cultural sustainability.
\end{abstract}

\section{Keywords}

Law and Society, Property Law, Municipal Law, Urban Spaces 


\title{
PROTECTING URBAN SPACES OF INTANGIBLE CULTURAL HERITAGE AND NIGHTLIFE COMMUNITY SUBCULTURAL WEALTH: INTERNATIONAL AND NATIONAL STRATEGIES, THE AGENT OF CHANGE PRINCIPLE, AND CREATIVE PLACEKEEPING
}

\author{
Sara Ross*
}

\section{INTRODUCTION}

Protecting and promoting diverse cultures and subcultures in urban environments requires an examination of how municipal and provincial legal frameworks govern the city space (e.g., urban planning policies, zoning decisions, and by law enforcement). This article explores potential paths toward the equitable regard, valuation, and sustainability of different cultural and subcultural existences in urban environments, with a particular focus on city redevelopment projects. Relying on urban legal anthropology, this paper will examine Toronto's "Music City" initiatives as aspects of Toronto's culture-based municipal development practices. The concepts of community subcultural wealth, use-value of urban spaces and properties, creative placekeeping, and buen vivir (or a "good life") in the city provide the theoretical foundation for the subsequent analysis of the different iterations of culture, cultural practices, and their associated spaces in Toronto, specifically, and municipalities, generally. ${ }^{1}$ The principal aim of this article is to convey the idea that intangible cultural heritage, and the subcultures in which it flourishes, are worthy of the same legislative and policy protections that are afforded to the dominant value systems. Such protections

Copyright C 2017 by SARA ROSS.

* Sara Ross is a PhD Candidate and Joseph-Armand Bombardier CGS Doctoral Scholar at Osgoode Hall Law School in Toronto. Sara holds five previous degrees, including a BA from the University of Alberta, BA Honours from McGill, both a civil law degree (BCL) and common law degree (LLB) from the McGill Faculty of Law, and an LLM from the University of Ottawa. She is a member of the Ontario bar and Instructor at Osgoode Hall Law School. This research was supported by the Social Sciences and Humanities Research Council of Canada. She would like to thank those attending the plenary panel of the Younger Comparativists Global Conference at Tulane University in New Orleans, where an earlier draft of this paper was presented, for their critical feedback, especially Professor Sally Richardson and Professor Jim Gordley.

${ }^{1}$ See generally Boaventura de Sousa Santos, Epistemologies of the South: Justice Against Epistemicide (Boulder: Paradigm Publishers, 2014) [Santos, Epistemologies] and especially at 2-16; see generally Arturo Escobar, Encountering Development: The Making and Unmaking of the Third World (Princeton: Princeton University Press, 2012) and especially at viii; see generally Eduardo Gudynas, "Buen Vivir: Today's Tomorrow” (2011) 54:4 Development 441 and especially at 441 [Gudynas, “Today’s Tomorrow”]; see generally Eduardo Gudynas, "Buen Vivir" in D’Alisa, Giacomo, Federica Demaria \& Giorgos Kallis, eds, Degrowth: A Vocabulary for a New Era (Abingdon, Oxon: Routledge, 2015) 201 and especially at 202. 
include economic exchange-value (i.e., market price) and tangible cultural heritage. The secondary, related aim is to examine the potential legal mechanisms that could protect and promote intangible cultural heritage. In so doing, this article will survey international legal frameworks for the protection of intangible culture to demonstrate that they remain under-utilized at the level of municipal governance of space and property. This article will also examine other legal mechanisms, governing property and nuisance - such as the agent-of-change principle - that could similarly be relied upon to protect and promote intangible cultural heritage.

\section{Cultural Space, Cultural Practices, and Properties of Culture in the City}

\section{What is Intangible Cultural Heritage?}

This article takes as its starting point the importance of protecting and promoting the diversities of cultures and cultural practices. As "culture" is neither easily nor concretely defined, ${ }^{2}$ I draw on the United Nations Educational, Scientific and Cultural Organization's (UNESCO) Universal Declaration on Cultural Diversity definition, since it is both expansive and flexible: "[T]he set of distinctive spiritual, material, intellectual and emotional features of society or a social group, and that it encompasses, in addition to art and literature, lifestyles, ways of living together, value systems, traditions, and beliefs." 3

When the modifier "intangible" is added, that which constitutes "culture" is further abstracted and becomes an even more elusive term: as a result, determining cultural heritage becomes more difficult. Indeed, although an "ignored heritage" for a long time, intangible cultural heritage makes a far more recent appearance within available international legal mechanisms interested in safeguarding cultural heritage. ${ }^{4}$ Article 2(1) of the 2003 UNESCO Convention on the Safeguarding of the Intangible Cultural Heritage ("2003 ICH Convention") provides the following definition for "intangible culture":

\footnotetext{
${ }^{2}$ Wim Van Zanten, “Constructing New Terminology for Intangible Cultural Heritage” (2004) 56:1-2 Museum International 36 at 37.

${ }^{3}$ Universal Declaration on Cultural Diversity, GA Res 25, UNESCOR, 31st Sess, Supp No 1, UN Doc $31 \mathrm{C} / 25$ (2001) 61 at 62 (adopted on 2 November 2001).

${ }^{4}$ Our Creative Diversity: Report of the World Commission on Culture and Development, UNESCO, 2001 at 30. See also, Dawson Munjeri, "Tangible and Intangible Heritage: From Difference to Convergence" (2001) 56:1-2 Museum International 12 at 13. Also, cf e.g. Convention Concerning the Protection of the World Cultural and Natural Heritage, 16 November 1972, 1037 UNTS 151 (entered into force 17 December 1975); UNESCO Convention on the Safeguarding of the Intangible Cultural Heritage, 2003, 2368 UNTS 3 (entered into force 20 April 2006) [2003 ICH Convention]; Declaration on the Principles of Tolerance (adopted 16 November 1995 by UNESCO, 28th Mtg (1995). For an explanation of the history leading up to the development of an international framework for protecting intangible cultural heritage, see Richard Kurin, "Safeguarding Intangible Cultural Heritage in the 2003 UNESCO Convention: A Critical Appraisal” (2004) 56:1-2 Museum International 66 at 67-69 [Kurin, "A Critical Appraisal"].
} 
[T]he practices, representations, expressions, knowledge, skills - as well as the instruments, objects, artefacts and cultural spaces associated therewith-that communities, groups and, in some cases, individuals recognize as part of their cultural heritage. This intangible cultural heritage, transmitted from generation to generation, is constantly recreated by communities and groups in response to their environment, their interaction with nature and their history, and provides them with a sense of identity and continuity, thus promoting respect for cultural diversity and human creativity. ${ }^{5}$

The foregoing is more akin to a description than a true definition. ${ }^{6}$ In this context, it is helpful to consider three requisite elements of intangible cultural heritage as it is applied internationally: "[A] manifestation of such heritage (objective component), a community of people (subjective or social component) and a cultural space (spatial component)."7 It encompasses human cultural activity and actions that extend beyond the mere utilitarian. ${ }^{8}$ It is "shared within and symbolically identified with a cultural community," and is passed on through traditions, genealogically or otherwise. ${ }^{9}$ In sum, intangible cultural heritage is a distinctive and non-corporeal shared feature of a community that is informed by its history and is contemporaneously manifested within and amongst members in a specific place or location (defined broadly). The cultural community in question does not need to be ethnically or regionally based, which allows for and results in modern cultural forms (e.g., cultural anthropologist, Richard Kurin cites modern dance and rap music as examples, among others). ${ }^{10}$

\section{Protecting Spaces of Culture and Properties of Intangible Culture}

Dense city spaces provide both the critical mass for groupings of like-minded individuals as well as a cover of anonymity that encourages the development of

\footnotetext{
${ }^{5}$ The 2003 ICH Convention also explains at Article 2(2) that intangible cultural heritage "is manifested inter alia in the following domains: (a) oral traditions and expressions, including language as a vehicle of the intangible cultural heritage; (b) performing arts; (c) social practices, rituals and festive events; (d) knowledge and practices concerning nature and the universe; (e) traditional craftsmanship." Article 2(3) goes on to specify that "safeguarding" signifies "measures aimed at ensuring the viability of the intangible cultural heritage, including the identification, documentation, research, preservation, protection, promotion, enhancement, transmission, particularly through formal and non-formal education, as well as the revitalization of the various aspects of such heritage."

${ }^{6}$ See e.g. Tullio Scovazzi, "The Definition of Intangible Cultural Heritage" in Silvia Borelli \& Federico Lenzerini, Cultural Heritage Rights, Cultural Rights, Cultural Diversity: New Developments in International Law (Leiden: Martinus Nijhoff Publishers, 2012) 179 at 180.

${ }^{7} \mathrm{Ibid}$. Scovazzi derives these elements from the practices of the Intergovernmental Committee for the Safeguarding of the Intangible Cultural Heritage in their creation and maintenance of the lists of intangible cultural heritage that are mandated by the 2003 ICH Convention.

${ }^{8}$ Kurin, “A Critical Appraisal”, supra note 4 at 69.

${ }^{9} \mathrm{Ibid}$.

${ }^{10}$ Ibid.
} 
subcultures and countercultures. ${ }^{11}$ Spaces of (and for) culture are crucial to cultures and subcultures' development and sustenance in cities. Within the city space, a cultural and subcultural group "creates its own geography, a set of places or sites ... through which it gains cohesion and identity." 12 Attending and participating within a space or venue can generate a spirit of community and belonging (e.g., a local store catering to repeat attendees with shared cultural reference points, preferences, and tastes). ${ }^{13}$ Beyond their economic value, these spaces are valuable because they serve as centers of belonging and congregation; thus, spaces and venues play a key role as a safe space and a nucleus for the development and flourishing of friendships, relationships, and community connections. ${ }^{14}$ Their safeguarding speaks to the kind of cultural and neighbourhood vibrancy espoused by nascent frameworks for city-based human rights charters - such as the Global Charter-Agenda for Human Rights in the City, the European Charter for the Safeguarding of Human Rights in the City, and Canada's Montreal Charter of Rights and Responsibilities - that seek to safeguard culture, cultural spaces, and the right to the city and culture in the city. ${ }^{15}$

In decisions pertaining to urban re-development and preservation strategies that affect or target a city's cultural and subcultural spaces, a space's meaningfulness (i.e., that which holds great community cultural wealth or a community's intangible cultural heritage) can be outweighed by its commercial viability or exchange-value of a space. ${ }^{16}$ These spaces are often undervalued through a prioritization of a space's marketability and exchange-value, to the detriment of that which brings cultural vitality and meaning to the space and its surrounding area. This results in the inequitable valuation of culture

\footnotetext{
${ }^{11}$ Iris Marion Young, Justice and the Politics of Difference (Princeton: Princeton University Press, 1990) at 238 .

12 Ken Gelder, Subcultures: Cultural Histories and Social Practice (London, UK: Routledge, 2007 ) at 2.

${ }^{13}$ Katherine N Rankin, Kuni Kamizake \& Heather McLean, “Toronto's Changing Neighborhoods: Gentrification of Shopping Streets” in Sharon Zurkin, Philip Kasinitz \& Xiangming Chen, eds, Global Cities, Local Streets: Everyday Diversity from New York to Shanghai (New York: Routledge, 2016) 140 at $154,159$.

${ }^{14}$ See e.g. Benjamin Boles, "Fight for Your Right to Party", NOWToronto (15 May 2014), online: $<$ nowtoronto.com> [Boles, "Fight"].

${ }^{15}$ Rankin, Kamizaki \& McLean, supra note 13 at 161, 165; Global Charter-Agenda for Human Rights in the City (drafted by social movements gathered in the World Social Forum in Porto Alegre, Brazil (2001)), online: UCLG Committee on Social, Inclusion, Participatory Democracy and Human Rights $<$ www.uclg-cisdp.org/en/right-to-the-city/world-charter-agenda>; European Charter for the Safeguarding of Human Rights in the City, 2000, online: UCLG Committee on Social, Inclusion, Participatory Democracy and Human Rights <www.uclg-cisdp.org/en/right-to-the-city/european-charter $>$. For Montreal, Quebec, see online: City of Montreal, Montréal Charter of Rights and Responsibilities (1 January 2006), online <ville.montreal.qc.ca> [Montreal City Charter].

${ }^{16}$ John R Logan \& Harvey L Molotch, Urban Fortunes: The Political Economy of Place (Berkeley: University of California Press, 1987) at vii-xii.
} 
and community cultural wealth that may exist, ${ }^{17}$ which can be detrimental to relationally vulnerable, cultural minority groups in the city space. ${ }^{18}$

Subcultural vulnerability is generated when subcultural interests clash, compete, or must be compared with more dominant, accepted, or visible cultural iterations that can be characterized as less disruptive in their use of spaces and properties in the city. As Ken Gelder's work on subcultural geographies reveals, "[S]ocieties at various times and for various reasons have legislated against [subcultures] and attempted to regulate and/or reform them." 19 This is apparent in the legal geographies and sociologies of nightlife cultural practices (e.g., club dancing) and their use of city space. ${ }^{20}$ One group that generates and sustains these genres of subcultural spaces and uses is youth. ${ }^{21}$ For example, they contribute to, and sustain, these spaces through their consumption of music within the space, or through entrepreneurial or employment opportunities available within nightlife cultural production. ${ }^{22}$ This subset of city-dwellers, though, is not usually effectively considered in the context of municipal planning and redevelopment decisions that regulate or redesign these spaces, namely sites of nightlife cultural practice and "unowned" spaces of youth subcultural production and consumption. $^{23}$

It is common for subcultural groups, such as youth, to tend toward using space in unconventional ways and at unconventional times in contrast to dominant societal day/night use patterns and norms. ${ }^{24}$ While these marginal and unconventional spaces' use-value and occupation patterns may be high for the subcultural groups in question,

\footnotetext{
${ }^{17}$ Tara J Yosso, "Whose Culture has Capital? A Critical Race Theory Discussion of Community and Cultural Wealth" (2005) 8:1 Race Ethnicity and Education 69.

${ }^{18}$ Ibid.

${ }^{19}$ Gelder, supra note 12 at 2.

${ }^{20}$ See e.g. Laam Hae, The Gentrification of Nightlife and the Right to the City: Regulating Spaces of Social Dancing in New York (New York: Routledge, 2012) at 5; Deborah Talbot, Regulating the Night: Race, Culture and Exclusion in the Making of the Night-time Economy (Hampshire: Ashgate, 2007) at 85, 132-33; Paul Chatterton \& Robert Hollands, Urban Nightscapes: Youth Cultures, Pleasure Spaces and Corporate Power (London, UK: Routledge, 2003) at 235.

${ }^{21}$ Examples of these kinds of subcultures could include many groups: the afterhours electronic dance music ("EDM") subcultural community, Do-It-Yourself ("DIY") music communities like the Queercore community in Toronto, the B-boy/B-girl dance subculture, skateboard or parkour communities, graffiti and street art subcultural communities, steampunk subcultural communities, drum-n-bass ("DnB") and junglist music communities, etc.

${ }^{22}$ See e.g. Miranda Campbell, Out of the Basement: Youth Cultural Production in Practice and Policy (Montreal: McGill-Queen's University Press, 2013) at 3; Chatterton \& Hollands, supra note 20 at 5, 71, 88-89, 209-10; Hae, supra note 20 at 40; Ernst \& Young, "Creating Growth: Measuring Cultural and Creative Markets in the EU" (December 2014) at 5-6, online:

$<$ http://www.ey.com/Publication/vwLUAssets/Measuring_cultural_and_creative_markets_in_the_EU $>$.

${ }^{23}$ UN-Habitat, Habitat III Issue Paper \#6, "Urban Rules and Legislation" (31 May 2015) at 2 [Habitat III Issue Paper \#6, "Urban Rules"]. See also Sharon Zukin, Naked City: The Death and Life of Authentic Urban Places (Oxford: Oxford University Press, 2010) at 6; Steven Miles \& Malcolm Miles, Consuming Cities (New York: Palgrave Macmillan, 2004) at 58; Campbell, supra note 22 at 3.

${ }^{24} \mathrm{Hae}$, supra note 20 at 40; Talbot, supra note 20 at 132-33.
} 
chances are that these same spaces and use patterns will not carry a high exchangevalue if examined within the urban legal frameworks governing city development projects. $^{25}$ The relative lack of protection for these subcultural groups through municipal legal frameworks reflects this weakness in exchange-value. ${ }^{26}$

\section{Music Spaces and the Preservation of Spaces of Subcultural Practice in the City}

Municipal governments across the world strive to attain the sought-after UNESCO moniker of a "Music City" in order to harness the corresponding potential housed within a vibrant music economy; however, music heritage and its associated spaces are given less consideration where an economic benefit is not immediately obvious. ${ }^{27}$ Music spaces are spaces of community cultural wealth and intangible cultural heritage that have a high use-value for production, consumption, and cultural flourishing within the city space. From a predominantly exchange-value perspective, a developed music culture in a city "generates jobs and attracts investment." 28 More importantly, Amy Terrill, Music Canada VP Public Affairs, also acknowledges that " $[\mathrm{t}]$ here is merit in preserving and protecting heritage, not just for the purpose of explaining where we came from, but also, in order to ensure a vibrant and healthy future. Music brings vitality and diversity to our cities. It bridges cultures and languages." 29 These spaces are important intercultural contact zones where culture in the city is generated and other cultural adherences are transcended. Further, such sites are where transgressive intercultural translation is facilitated through the common use of, and interest in, a space. ${ }^{30}$

${ }^{25}$ Chatterton \& Hollands, supra note 20 at 208.

${ }^{26}$ Ibid at 204; Habitat III Issue Paper \#6, "Urban Rules" supra note 23 at 2.

${ }^{27}$ For a list of "official" Music Cities, see UNESCO, "Creative Cities Network", online:

$<$ en.unesco.org/creative-cities/home>. As one of the key guiding documents in "becoming" a Music City explains: The term "Music City" is becoming widely used in cultural communities and has penetrated the political vernacular in many cities around the world. Once identified solely with Tennessee's storied capital of songwriting and music business, Nashville, Music City now also describes communities of various sizes that have a vibrant music economy which they actively promote. See International Federation of the Phonographic Industry \& Music Canada, "The Mastering of a Music City: Key Elements, Effective Strategies and Why it's Worth Pursuing" (5 June 2015), Music Canada, online: $<$ musiccanada.com> [IFPI \& Music Canada, "Mastering a Music City"].

${ }^{28}$ Amy Terrill, "Making Music History Work for the Present", (21 December 2015) Huffington Post (blog), online: <www.huffingtonpost.ca $>$.

${ }^{29}$ Ibid.

${ }^{30}$ See Hae, supra note 20 at 6. See also Santos, Epistemologies, supra note 1 at 227; Boaventura de Sousa Santos, Toward a New Legal Common Sense, 2nd ed (London, UK: Butterworths LexisNexis, 2002) at 472 [Santos, Toward]. For Santos, contact zones are "social fields in which different normative [and cultural] life worlds meet [negotiate] and clash" (ibid; Santos, Epistemologies, supra note 1 at 218), and where "rival normative ideas, knowledges, power forms, symbolic universes and agencies meet in unequal conditions and resist, reject, assimilate, imitate, and subvert each other, giving rise to hybrid legal and political [and cultural] constellations in which the inequality of exchanges are traceable [and may be either reinforced or reduced]" (Santos, Toward, ibid at 472; Santos, Epistemologies, supra note 1 at 218). 
While statements such as Terrill's appear to indicate a greater concern with preserving the intangible cultural heritage of music and music spaces in Canadian cities, a broad picture of "music" is being painted, where subsets of music communities remain underrepresented and dismissed. Music culture and spaces that are found further along the spectrum of unconventional day/night use patterns - or that fit less neatly into views of how music might bring gains to a city's economic, cultural, and tourism reputation-do not figure into nascent discussions regarding preservation and protection.

Excavating the saga of various music communities in Toronto-such as the Electronic Dance Music (EDM) scene and its related events, which have faced bans at various points - it bears noting that even where " $[\mathrm{t}]$ he vast majority on [city] council agreed that targeting a specific subculture is absurd ... many of them have long encouraged a subtler and more systematic battle against dance music when it comes to venues in their own wards." 31 In Toronto, "[b]ars that focus on musical entertainment are constantly under attack for not having entertainment facility permits, yet it is nearly impossible to get that classification, even along main streets where most people expect those establishments to be." 32 While Toronto's music and nightlife cultures generally face an ongoing struggle against a daunting array of overly zealous zoning restrictions, liquor licensing requirements, and by laws, ${ }^{33}$ venues with even less conventional day/night use patterns, such as afterhours music spaces and clubs, are on additionally precarious footing.

Centrally located in Toronto's downtown core, Comfort Zone is one of Toronto's last remaining afterhours clubs. Comfort Zone operates primarily on weekends, when most of the city's bars and other music and dance spaces have closed for the night, and the city is largely asleep. It is usually open from about 12:00 am or 2:00 am, until between 5:00 am or 11:00 am, and is infamous for its sunset-to-sunrise hours, its Sunday daytime dance parties, and its 24-hour dance marathons. ${ }^{34}$ Comfort Zone is seen as a space for past and present DJs to develop and hone their craft. ${ }^{35}$ In early 2016, the venue launched a \$23 million lawsuit against The Toronto Police Service. ${ }^{36}$ The suit alleges an eight-year campaign of intimidation and abuse of power

\footnotetext{
${ }^{31}$ Boles, "Fight", supra note 14.

${ }^{32}$ Ibid.

${ }^{33}$ Ibid; Terrill, supra note 28; Carl Grodach, "City Image and the Politics of Music Policy in the 'Live Music Capital of the World"' in Carl Grodach \& Daniel Silver, eds, The Politics of Urban Cultural Policy: Global Perspectives (London, UK: Routledge, 2013) 98 at 100. See also Zukin, supra note 23 at 102.

${ }^{34}$ See e.g. Lee Trotter, "Afterhours in Toronto: A Look Inside Comfort Zone”, 6am Group (25 August 2015), online: $<6$ am-group.com>. See also the Comfort Zone website, online: $<$ comfortzonetoronto.com $>$.

${ }^{35}$ Ibid.

${ }^{36}$ Christopher Reynolds, "After-hours Club Sues Toronto Police, Alleging 'Abuse of Power'”, thestar.com (3 January 2016), online: <www.thestar.com>.
} 
stemming from a sting operation called Operation White Rabbit, which began in 2008 and was instituted in response to a GHB (Gamma Hydroxybutyrate) ${ }^{37}$ overdose from drugs that were allegedly purchased at Comfort Zone. This lawsuit follows another in 2009 against the then Toronto City Councillor Adam Vaughan for what Comfort Zone alleged to be a systematic harassment campaign and, specifically, claimed "misfeasance in public office, abuse of public office, unlawful interference with economic relations and conspiracy to defame and injury." 38 In relation to what is viewed as differential treatment by Toronto's regulatory and law enforcement mechanisms, Comfort Zone's lawyer, Barry Swadron, is of the opinion that Comfort Zone serves a useful purpose by catering "to that sector of the population who wish to listen to music, dance, eat, and enjoy themselves after the closing hours of bars and nightclubs". ${ }^{39} \mathrm{He}$ also believes that the city and police service should recognize and respect this practice. ${ }^{40}$ For Swadron, "Toronto is a world-class city and the after-hours community want and should have a place to go." ${ }^{\prime 1}$ Where the desire for this type of space is ignored or wilfully supressed, the risk is "to force facilities like Comfort Zone to go underground to serve the afterhours community." 42 Such legal action is significant because these kinds of spaces do not often, and are not often able to, seek legal redress in response to perceived injustices. $^{43}$

While such lawsuits themselves can be effective in highlighting differential treatment received by subcultural spaces in the city, Comfort Zone has already lost its battle to exist on another front. City redevelopment, rezoning, and planning by laws have enabled a proposal from the building's owner to have it redeveloped into a parkade to service a private student living development. ${ }^{44}$ While an inquiry regarding the

\footnotetext{
${ }^{37}$ Centre for Addiction and Mental Health (CAMH), "GHB", (2012), online: < http://www.camh.ca >.

${ }^{38}$ Kirk Makin, "Nightclub Sues City for Harassment", The Globe and Mail (9 March 2009), online: $<$ www.theglobeandmail.com>; Donovan Vincent, "Comfort Zone Dance Club Sues Over 'Unfair Scrutiny", thestar.com (10 March 2009), online: <www.thestar.com>. Benjamin Boles, "Revenge of the Comfort Zone", Now Toronto (12 March 2009), online: <nowtoronto.com>.

${ }^{39}$ Reynolds, supra note 36 (quoting Barry Swadron).

${ }^{40}$ Sam Pazzano, "Cops Hit with Club Suit", Toronto Sun (2 January 2016), online: $<$ www.torontosun.com>.

${ }^{41}$ Reynolds, supra note 36 (quoting Barry Swadron).

${ }^{42}$ Pazzano, supra note 40 (quoting Barry Swadron).

${ }^{43}$ See e.g. Kurtis Hooper, “Toronto's Comfort Zone is Suing Police for \$23 Million”, TRC trc.dailybeat.com (2 January 2016), online: <trc.daily-beat.com>; Jeffrey Yau, "Toronto After-Hours Comfort Zone Looks to Sue Police for \$23 Million”, YOUREDM (2 January 2016), online: <www.youredm.com>. 44 "484 Spadina by Wynn Group Residential", online: <urbantoronto.ca>; Richard Longley, "Waverly Goodbye", NOW Toronto (17 June 2015), online: <nowtoronto.com>. The approved proposal for the residence followed a battle over arguments for the Waverly's potential heritage designation. The Waverly's application for heritage designation failed, but the attached Silver Dollar Room, as outlined further below, did receive heritage designation status that protects it from demolition and redevelopment. See Toronto Preservation Board, Agenda Item PB 3315, "Heritage Evaluation - 484 Spadina Avenue Waverley Hotel" (17 July 2014); City of Toronto, by-law No 57-2015, To designate the property at 484 Spadina Avenue (Silver Dollar Room) as being of cultural heritage value or interest (11 December 2014) [By-law No 57-2015].
} 
historical, heritage, and community merits of the other two businesses attached to Comfort Zone - the Waverly Hotel, a historical hotel, and the Silver Dollar Room, discussed further below in relation to its recent heritage designation-occurred prior to approval of the redevelopment and rezoning proposal, no inquiry into the Comfort Zone space was made. Neither was any consultation, reference, or effort made to engage with Comfort Zone's soon-to-be displaced community that regularly occupies the least active hours of the city's day/night continuum.

This lack of regard for the intangible cultural heritage of the Comfort zone space seems entirely consistent with what a reasonable person would expect might, and possibly even believe should, happen when a municipality engages in redevelopment decision-making. However, in accordance with the primary aim of this article, it is argued that the normative dimensions of traditional municipal development and zoning policy ought to be broadened to include notions of intangible cultural heritage. The traditional valuation scheme is defective because it ignores one of the main contributors to the overall value of the space: its subcultural and cultural vitality. While exchange value and tangible cultural heritage are certainly relevant valuation schemes, limiting municipal development policy to these dominant schemes is an incomplete and potentially short-sighted approach. In some instances, the intangible cultural heritage merits of spaces should be considered and, if necessary, protected when municipalities consider development proposals.

It is the intangible cultural heritage that contributes to the buen vivir, or the "fullness of life" in a community. ${ }^{45}$ Protection of intangible cultural heritage benefits those individuals who are directly associated with, and derive meaning from, the specific subculture or culture. It can also simultaneously promote dominant iterations of value (e.g., exchange value) for the benefit of the municipality as whole. For instance, from the municipality's perspective, the protection and promotion of intangible cultural heritage can help ensure that the city remains, or becomes, a place where people want to live or visit. Placing an undue priority on exchange-value when considering city redevelopment policy will yield diminishing returns if the policy either sacrifices or ignores what initially drew people to the location and the city.

If we assume that property market-exchange values are directly linked with the desirability of a neighbourhood or city, it would be incongruous with "big-picture" market vitality to ignore what makes the neighbourhood or city desirable: in many cases, it is its cultural "well being." The idea of buen vivir "acknowledges that there are several ways to give value, such as aesthetic, cultural, historical, environmental, spiritual, and so on."46 While individual property owners can disagree, municipalities ought to, given their public mandate, place a greater emphasis on non-dominant value

${ }^{45}$ Gudynas, “Today's Tomorrow”, supra note 1 at 442.

${ }^{46}$ Ibid at 445. 
sources when they make development and zoning decisions. This is a viable means of simultaneously promoting and protecting the economic and cultural vitality of the municipality.

The current lack of regard for the subcultural value of places like Comfort Zone is due to a number of oversights in designing city by laws dealing with redevelopment proposals. Directly, this may result from a lack of regard for the interests of the subcultural community, but it might equally be the result of the invisibility of subcultural occupiers during daytime hours when the space is used primarily during the nightlife period of the day/night continuum. In such a case, if the space or property is examined for potential communities affected by proposed redevelopment, a daytime assessment would likely fail to reveal the attached subcultural community and, more importantly, would not enable meaningful engagement with temporally unconventional occupiers of the space. Ultimately, alternative or unconventional occupation tends to be stifled by municipal governance structures dealing with redevelopment, preservation, and promotion of city spaces, which operate without regard for the flourishing of subcultural communities that inhabit the spaces in question. ${ }^{47}$

Comfort Zone is but one Toronto example of a subcultural space that has been sold, demolished, or redeveloped under the feet of the lessee, operator, and occupants of the space by the owner. The iconic Toronto music venue Guvernment was recently sold out from under the venue operator despite attempts to buy the space in order to save it from demolition and replacement with a high-end waterfront mixed-use condo and arts development known as "Daniels Waterfront-City of the Arts". 48 This ended Guvernment's nearly twenty-year history of contributing to Toronto and Canada's music culture, electronic music scene, and drum ' $n$ ' bass music community, as well as its availability as an important development site for nascent young entrepreneurs, musicians, DJs, and promoters within the music community.

\footnotetext{
${ }^{47}$ Hae, supra note 20 at 3 . For a Toronto-based example of purposeful stifling of unruly venues in Toronto, see e.g. Sebastien Darchen \& Diane-Gabriel Tremblay, "The Local Governance of Culture-led Regeneration Projects: A Comparison between Montreal and Toronto" (2013) 6:2 Urban Research \& Practice 140 at 150 .

${ }^{48}$ Jane Stevenson, "Legendary Guvernment Nightclub Faces Wrecking Ball”, Toronto Sun (25 January 2015), online: <www.torontosun.com>. See also "Groundbreaking Plans Unveiled for Daniels Waterfront - City of the Arts at Former Guvernment Entertainment Complex”, Business Wire (26 March 2015), online: <www.businesswire.com> ["Groundbreaking Plans"]; David Shum, "Daniels Corporation Unveils Waterfront Mixed-Use Condo Project”, Global News (26 March 2015), online: <globalnews.ca>; Susan Pigg, "\$700-Million Arts-Focused Complex Planned for Queens Quay Site”, Toronto Star (26 March 2015), online: www.thestar.com>; "Waterfront Condos by Daniels Corp", Daniels Waterfront Condos, online: <danielswaterfrontcondos.ca> [Daniels Waterfront Condos]. See also the planning application for the Daniels Waterfront development: \#14 249503 STE 28 SA for 142 Lake Shore Blvd East, online: Toronto Development Projects <app.toronto.ca> ["Daniels Waterfront Planning Application"].
} 
After the approval of the planning application by the new owner, Toronto Mayor John Tory (a vocal proponent of Toronto's aspirations for becoming an internationally renowned "Music City"), somewhat paradoxically, stated:

The revitalization of our waterfront is one of Toronto's most exciting and challenging urban renewal projects. Daniels' [sic] vision for the former entertainment complex site [Guvernment] is a groundbreaking project that will have a lasting cultural legacy. Not only will this site feature landmark residential and office towers, but it will also be home to student innovation and a hub for the creative industries. The project will complement the future East Bayfront community, further adding to the diversity of our waterfront while creating jobs that are central to our city's growth. ${ }^{49}$

In a manner that perhaps acknowledges its role in displacing an important piece of Toronto's community subcultural wealth and intangible music heritage, the Daniels Corporation's sales website for the new complex summarizes the former occupant (Guvernment) of the space as follows:

The club finally closed its doors on January 31st, 2015. Formerly the RPM nightclub for about 10 years which brought legends like the Beastie Boys and made former Jamaican born Canadian DJ Chris Sheppard into a superstar in the dance music world. Now currently the Guvernment nightclub which opened its doors in 1996 where superstars such as Lady Gaga and the Rolling Stones played and where DJ Deadmau5 got his start. Charles Khaboth [sic], owner of INK Entertianment [sic] tried to buy the building with his partners but were unsuccessful as Daniels Corp. has bought it to turn the site at Queens Quay and Lower Jarvis into residential and commercial properties known as the Daniels Waterfront Condos. ${ }^{50}$

Guvernment merely follows on the tails of other displaced music venues and their operators who did not (or were not able to) sustain ownership of spaces they curated for various subcultural communities throughout Toronto.

For years, musical subcultures were able to sidestep a lack of acceptance or unequal treatment by municipal legal governance frameworks and related zoning by laws and planning legislation by occupying unwanted and undesirable spaces - the areas of the city characterized by abandoned warehouses and factories. While this, temporarily, helped numerous groups establish rich communities, cultures, spaces, and practices, the post-industrial shift has put these formerly undesirable spaces back on the map of desirable space as cities strive to "reclaim" their industrial past. Municipalities

\footnotetext{
${ }^{49}$ See "Groundbreaking Plans", supra note 48. See also the Daniels Waterfront Planning Application, supra note 48.

${ }^{50}$ Daniels Waterfront Condos, supra note 48.
} 
seeking to take back zones formerly dedicated to industry and factories are turning toward progressively residentially-focused zoning policy in these areas. Municipalities are instead catering to those able to afford the newly attractive and commodified authenticity of these post-industrial spaces transformed and branded into urban playgrounds. This shift has placed those formerly using the abandoned and unwanted spaces at risk of being pushed out, priced out, and unwelcome.51As San Francisco Cultural Affairs Director Tom DeCaigny explains,

The one thing we know is that urbanization is on the rise around the globe. So more and more people are moving into cities because they want the arts and culture the city has to offer, but land becomes more valuable. So it's about how we create pathways of ownership for artists and arts organizations so they're not forced to deal with the broader markets that tend to be more aggressive than artists can afford. ${ }^{52}$

Many subcultural community groups rely on the availability of these warehousetype spaces on a temporary or rotating basis. These kinds of use patterns are even harder to protect or preserve due to their impermanence and transience; however, they nonetheless serve an important role in providing affordable space for production companies, young entrepreneurs, musicians, and other subcultural actors. In this context, it becomes even more important to preserve the remaining permanent types of welcoming and affordable music spaces previously mentioned that can still be accessed for events by these groups. ${ }^{53}$

\section{Strategies for the Better Valuation, Protection, and Promotion of Subcultural Spaces}

\section{The Utility of International Cultural Heritage Legislation}

In determining which spaces and properties of intangible cultural heritage should be protected, Richard Kurin explains that it "is the dynamic social processes of creativity, of identity-making, of taking and respecting the historically received and remaking it as one's own that is to be safeguarded." 54 Yet this still leaves open the role of the "arbiter of value" in determining what should be protected. In terms of this role,

\footnotetext{
${ }^{51}$ Zukin, supra note 23 at x-xiii, 3-4, 23-24, 111-12.

52 Interview of Tom DeCaigny by Cy Musiker (27 November 2015) in “How to Keep a City's Economic Growth from Destroying its Cultural Soul?", KQED Arts, online: <ww2.kqed.org> [Interview of Tom DeCaigny].

53 See also "World Cities Culture Report 2015", World Cities Culture Forum, online: $<$ www.worldcitiescultureforum.com $>$ at 20.

${ }^{54}$ Richard Kurin, "Safeguarding Intangible Cultural Heritage: Key Factors in Implementing the 2003 Convention" (Inaugural Public Lecture delivered at the Smithsonian Institution and the University of Queensland MoU Ceremony, 23 November 2006), 02 Intl J Intangible Heritage 9 at 13 [Kurin, "Implementing the 2003 Convention"].
} 
Kurin states, "those who might be mindful of variants and yet decide on their relative significance and correctness-are not governments or scholars or collectors or aficionados, but rather members of the concerned communities themselves." 55

Article 15 of the 2003 ICH Convention, entitled "Participation of Communities, Groups and Individuals," reads: "Within the framework of its safeguarding activities of the intangible cultural heritage, each State Party shall endeavour to ensure the widest possible participation of communities, groups and, where appropriate, individuals that create, maintain, and transmit such heritage, and to involve them actively in its management." While Kurin goes on to explain, "members of the communities whose heritage is being safeguarded are to be full partners with any and all [safeguarding] efforts," $" 57$ he warns that:

Governments, or university departments or museums, cannot just assume they have permission to define ICH and undertake its documentation, presentation, protection or preservation. Community participation is meant to be significant and meaningful - involving the consent of community leaders, consultation with lead cultural practitioners, shared decision-making on strategies and tactics of safeguarding and so on. ${ }^{58}$

Kurin is also sure to note that the $2003 \mathrm{ICH}$ Convention is flexible and allows for the protection of non-traditional notions of what constitutes cultural activities and forms, their related spaces, and associated cultural communities - with wide ranging examples such as "rap music, Australian cricket, modern dance, post-modernist architectural knowledge, and karaoke bars," to name a few." 59 While this assessment of the state of intangible cultural heritage at the international level is a helpful guide-where countries such as Canada and the United States have yet to ratify the 2003 ICH Convention-it bears examining the mechanics of how intangible cultural heritage is currently being dealt with on the ground level without reference to the $2003 \mathrm{ICH}$ Convention as well as the kinds of future mechanisms that might enable the recognition of different types of subcultural community wealth in the city.

\section{Protection of Intangible Cultural Heritage at the Provincial and Municipal Level}

There are a series of frameworks and bodies that ultimately govern what is or is not considered to be tangible heritage, including, inter alia, planning boards, heritage

\footnotetext{
${ }^{55}$ Ibid [emphasis added].

562003 ICH Convention, supra note 4.

${ }^{57}$ Kurin, "Implementing the 2003 Convention", supra note 54.

58 Ibid.

59 Ibid.
} 
boards, and municipal governance boards; however, a serious gap exists in intangible cultural heritage protection.

Provinces and municipalities address intangible cultural heritage using several strategies. Where cultural matters fall within provincial jurisdiction, some provinces have developed their own provincial legislation that acknowledges intangible cultural heritage. For example, Quebec's Cultural Heritage $A c t^{60}$ explicitly addresses the preservation of elements of intangible cultural heritage. ${ }^{61}$ Other instances, as detailed in the following section, have seen provinces such as Ontario at times read-in the notion of intangible cultural heritage into provincial tangible cultural heritage provisions. ${ }^{62}$ At the municipal level, while cities may have policies or boards that lobby for heritage preservation, this is largely in relation to tangible cultural heritage preservation. There are, however, outliers, such as Montreal's Charter of Rights and Responsibilities, which describes the protection of intangible culture and its heritage merits. ${ }^{63}$ Where explicit intangible cultural heritage protection is not an option, or where the legal infrastructure does not necessarily provide for the explicit acknowledgment or protection of intangible cultural heritage, other strategies exist, or are being developed, that can provide an equitable approach to valuating, acknowledging, protecting, and promoting diverse iterations of culture and subculture in the city.

Apart from reading-in the notion of intangible cultural heritage protection into existing tangible cultural heritage legislation, Toronto, in a recent landmark move, has taken a different route. The Silver Dollar Room received protection from a redevelopment proposal that threatened its continued existence through cultural heritage preservation legislation designed primarily for tangible heritage merits. The legislation was interpreted and deployed to preserve the Silver Dollar Room's intangible cultural heritage and the high subcultural community wealth generated within its space, divorced from any tangible merits. It received protection for the following reasons: (1) "by virtue of it being a well-known, long-standing destination for live music with an international reputation," (2) for "its contribution to Toronto's musical culture" as a space for the incubation of musical talent, (3) for its contribution to the "development

${ }^{60}$ Cultural Heritage Act, CQLR, c P-9.002 [CHA].

${ }^{61}$ Under the $C H A$, ibid, "culture heritage" is defined to include intangible cultural heritage at s 1 of the Act: "Cultural heritage consists of deceased persons of historical importance, historic events and sites, heritage documents, immovables, objects and sites, heritage cultural landscapes, and intangible heritage" (ibid). "Intangible heritage" is subsequently defined at Section 2 as "the skills, knowledge, expressions, practices and representations handed down from generation to generation and constantly recreated, in conjunction with any cultural objects or spaces associated with them, that a community or group recognizes as part of its cultural heritage, the knowledge, protection, transmission or enhancement of which is in the public interest" (ibid). For less developed but nonetheless nascent initiatives, see Government of Newfoundland and Labrador, "Creative Newfoundland and Labrador: The Blueprint for Investment and Development in Culture" (2006) at 34.

${ }^{62}$ See e.g. By-law 57-2015, supra note 44; Ontario Heritage Act, RSO 1990, c O.18; Criteria for

Determining Cultural Heritage Value or Interest, O Reg 9/06.

${ }^{63}$ Montreal City Charter, supra note 15. 
and growth of music in Toronto," and (4) for its role as a "workshop for new and sometimes struggling musicians, both local and transient, to sit in with more established musicians, to develop their music and build up a following." 64

\section{Creative Placekeeping and Conscientious Zoning Practices}

While the proliferation of a culture-based strategy for city development has many positive benefits, its bewitching properties can enable city governance structures to glaze over the problems that remain in the urban governance of culture and spaces of culture. Roberto Bedoya (former Executive Director of the Tuscon Pima Arts Council and art-based civic engagement strategies) writes of this in relation to what is known as "creative placemaking." "65 This term, as coined by Bedoya, derived from the community activist Jenny Lee's term "placekeeping," 66 is developed in an interview with DeCaigny, who explains the concept in the following way:

[a]s important as creative placemaking can be to improving the quality of life of a city, I think we also have to be concerned with creative placekeeping. ... [I]t's really about how do we insure as municipal governments that artists and arts organizations continue to thrive where they are. These are the people who have made our neighborhoods unique - that people want to come and be a part of. We want to welcome new people to the party, but we also want to make sure that they're respectful of the people who made this city such a great place to live in and play in in the first place. ${ }^{67}$

In relation to gentrification, Bedoya uses the term "placekeeping," with reference to Jenny Lee's use of the term, in the following manner:

\footnotetext{
${ }^{64}$ By-law No 57-2015, supra note 44; Ontario Heritage Act, supra note 62.

${ }^{65}$ The term "creative placemaking" first came onto the radar in a White Paper entitled "Creative Placemaking" written for the Mayors' Institute on City Design (a leadership initiative of the US National Endowment for the Arts) in 2010 by Ann Markusen and Anne Gadwa, online: $<$ www.arts.gov/sites/default/files/CreativePlacemaking-Paper.pdf. $>$. They provide the following definition: "in creative placemaking, partners from public, private, non-profit, and community sectors strategically shape the physical and social character of a neighborhood, town, city, or region around arts and cultural activities. Creative placemaking animates public and private spaces, rejuvenates structures and streetscapes, improves local business viability and public safety, and brings diverse people together to celebrate, inspire, and be inspired" (at 3). In addition, the UN-Habitat III, Issue Paper \#11, "Public Space", (31 May 2015) at 1, defines "placemaking" as referring to "a collaborative process of shaping the public realm in order to maximize shared value. More than promoting better urban design, placemaking facilitates use, paying particular attention to the physical, cultural, and social identities that define a place."

${ }^{66}$ Roberto Bedoya, "Spatial Justice: Rasquachification, Race and the City", CreativeTimeReports (15 September 2015), online: <creativetimereports.org>.

${ }^{67}$ Interview of Tom DeCaigny, supra note 52 [emphasis added].
} 
...not just preserving the facade of the building but also keeping the cultural memories associated with a locale alive, keeping the tree once planted in the memory of a loved one lost in a war and keeping the tenants who have raised their family in an apartment. It is a call to hold on to the stories told on the streets by the locals, and to keep the sounds ringing out in a neighborhood populated by musicians who perform at the corner bar or social hall. ${ }^{68}$

Drawing on the attention currently being paid by municipal legal governance structures in London, UK, to the threat of disappearance that subcultural music spaces are facing, the "Asset of Community Value" mechanism highlighted in London's recent Grassroots Music Venues Rescue Plan is in line with creative placekeeping strategy. It enables the acknowledgment of intangible cultural heritage and deals with the barrier created by a lack of ownership of subcultural community spaces. ${ }^{69}$ This means "[b]uildings that are successfully listed cannot be sold without first giving community groups the right to bid for them, in order to use them for community benefit."70

While operationalizing creative placekeeping through greater intangible cultural heritage management and preservation legislation, zoning practices and decisions also warrant examination. This is another area where municipal legislators and decisionmakers could more equitably consider the interests of subcultural community spaces. Creative placekeeping in this context might also mitigate the contributory effects that a lack of ownership of spaces has on the sustenance of these spaces of community subcultural wealth in the face of the post-industrial shift, both in terms of the use of spaces on a permanent basis and for transient event-based use. Where these spaces and properties that are not owned have already been lost by subcultural community actorssuch as Guvernment and Comfort Zone, among many others-DeCaigny examines the possibilities that conscientious zoning practices in line with creative placekeeping might provide:

One thing we've looked at locally [in San Francisco], something other cities have had success with, is the zoning of space that is most conducive to artists. In the US and San Francisco that is referred to as PDR, or Production, Distribution and Repair space. So if you've wondered why artists often find studios in spaces that are near auto repair or warehouses, it's because that's usually zoned PDR. So one of the things we're looking at here at the Arts Commission is how do we work with the Planning Department to ensure a good proportion of PDR, because that creates a market that artists can access. So the cost per square foot

\footnotetext{
${ }^{68}$ Bedoya, supra note 66.

${ }^{69}$ The Mayor of London's Music Venues Taskforce, "Rescue Plan: A Report for the Mayor, Music Industry, Local Authorities, Government, Planners, Developers, Licensers, Police, Economists, Tourism Agencies, Musicians, Culture Funders" (London, UK: Greater London Authority, 2015) at 25 [London's Music Venues Taskforce, "Rescue Plan"].

${ }^{70}$ Ibid.
} 
of that space tends to be lower. Other cities like London and Shanghai have found great success with equivalent zoning that protects space for artist use. ${ }^{71}$

Given the multitude of vibrant subcultural communities in Toronto that need to contend for their survival with high market-exchange values, ${ }^{72}$ Toronto should pay heed to a city like San Francisco, where the high cost of living is prohibiting cultural flourishing.

The Agent of Change Principle: Equalizing Neighbourhood Power Relations to Sustain Originate Subcultural Community Spaces

A particular threat that has led to the loss of music venues-from San Francisco to London to Toronto - arises when newcomers to a neighbourhood move in and then proceed to take issue with the existing sound levels, usually during nightlife portions of the day/night continuum. ${ }^{73}$ London is seen by many as leading the way in beginning to deal progressively with these issues through grassroots lobbying around the "agent-ofchange" principle, which, among other components, can restrict owners of new residences from making noise complaints against music venues in the neighbourhood. ${ }^{74}$

As grassroots organizations concerned with disappearing spaces of music culture begin to gain momentum, projects like the Music Venue Trust, a charity created in 2014 to protect the UK live music network, are springing up. ${ }^{75}$ A variety of legal and governance changes and responses are resulting from grassroots protection organizations and initiatives such as these. For example, the UK has followed the push of groups such as the Music Venue Trust in introducing aspects of the agent-of-change principle to existing nuisance laws in order to deal with the effect of noise complaints on preserving established music venues. ${ }^{76}$ This principle essentially enables a transfer of the onus onto developers to ensure that new developments incorporate sufficient soundproofing to meet the noise levels characteristic of the neighbourhood in question and disables much of the impact of noise concerns originating with occupants new to the area. $^{77}$ While not yet a fully developed agent-of-change law, the Music Venues

\footnotetext{
${ }^{71}$ Interview of Tom DeCaigny, supra note 52.

72 The Canadian Press, "Want a detached house in Toronto? You need \$1.29M", CBC News (5 October 2016), online: < http://www.cbc.ca/news/canada/toronto/>.

${ }^{73}$ Interview of Tom DeCaigny, supra note 52.

74 Ibid.

75 See e.g. http://musicvenuetrust.com/.

${ }^{76}$ See also London's Music Venues Task Force, "Rescue Plan”, supra note 69.

${ }^{77}$ See Toronto Music Advisory Committee, "Noise Bylaw Recommendations" (Toronto: TMAC, August 2015) at 11, online: <www.toronto.ca/legdocs/mmis/2015/ma/bgrd/backgroundfile-84014.pdf> [TMAC, "Noise Bylaw Recommendations]; Emily Sutherland, "Boris Johnson Gets Behind Campaign to Save Music Venues", The Publican's Morning Advertiser (22 October 2015), online: $<$ www.morningadvertiser.co.uk $>$. But see Sturges $v$ Bridgman (1879) 11 Ch D. 852, an English common law nuisance case where it was found that "a defendant could not rely on the defence that the complainant
} 
Trust, Musicians' Union, and UK Music secured a significant victory on April 6, 2016 when amended UK legislation came into force that protects music venues ("or any other place of public entertainment") from encroaching upon residential developments by requiring developers to first obtain noise impact approval from the local planning authority before transforming a building purposed for office space into residential spaces. ${ }^{78}$

Turning back to the case study of Toronto's Music City initiative, as Toronto looks into future noise by law revisions, the Toronto Music Advisory Council (TMAC) in their noise by law recommendation also considers the stymying effects of the current noise by law on live music venues. ${ }^{79}$ One of the main suggestions put forward by TMAC is for the adoption of this agent-of-change principle to safeguard "culturally rich or significant districts from development and gentrification, especially heritage properties and other special use properties such as entertainment establishments and concert halls." 80 Additionally, these recommendations are in line with, and draw from, the "Mastering of a Music City" study developed by the City of Toronto, which has become a resource that other cities (including, interestingly, the London, UK, music preservation initiatives) seek to follow in their respective quests to attain the elusive UNESCO status of a "Music City." 81

Where the agent-of-change principle is seen as helpful legislation by these Music City hopeful cities, Australia is often referred to for its application of the agentof-change principle, which took effect in 2014, subsequent to an Industry Position Paper by Music Victoria in 2012. The principle here applies not just to established venues but also to new music venues. ${ }^{82}$ Part of what makes the agent-of-change principle so

came to the nuisance. In this instance, case law found it does not matter who was there first. The overriding concern is whether the noise maker is being unreasonable. See also Gwyn Mapp, "The Agent of Change Principle, Noise from Music Venues and Recent Case Law", Noisewise: Wise About Noise (28 April 2015), online: <www.noisewise.com>. While the fact that a claimant "came to the nuisance" may be taken into account in the court's assessment of a noise/nuisance situation, the agent of change principle more effectively accounts for, and protects, the originate occupant within the neighbourhood. See also for an interesting take on noise complaints: Mark Davyd, "How to Save Live Music in the UK", (31 August 2014) Huffington Post (blog), online: <www.huffingtonpost.co.uk> .

${ }^{78}$ Town and Country Planning (General Permitted Development) (England) (Amendment) Order 2016, SI 2016/332, s 7; Emma Garland, "Finally! A Law Has Been Passed That Will Actually Protect UK Music Venues From Developers", Noisey (14 March 2016), online: < noisey.vice.com>.

${ }^{79}$ TMAC's "Noise Bylaw Recommendations", supra note 77. Toronto's competing city initiatives have, on the one hand, seen Toronto attempt to start along the path to becoming a well-known branded "Music City" but have, on the other hand, held grassroots music venues and ventures back with things like a facilitation of the complaint mechanisms for citizen noise concerns (Josh O'Kane, "Toronto Venue Owners Have to Deal with Tough Music-Related Bylaws", The Globe and Mail (31 July 2015), online: $<$ www.theglobeandmail.com $>$ ).

${ }^{80}$ TMAC's "Noise Bylaw Recommendations", supra note 77 at 11-12; O'Kane, supra note 79.

${ }^{81}$ IFPI \& Music Canada, "Mastering a Music City", supra note 27 at 42.

${ }^{82}$ Music Victoria, "Music Industry Position Paper - The Case for Regulatory Reform" (July 2012), online: <musicvictoria.com.au/assets/Documents/Music_Victoria_position_paper_Li.pdf $>$. See also TMAC's "Noise Bylaw Recommendations", supra note 77 at 11; Stephanie Chalkley-Rhoden, 
attractive is that it opens a dialogue between parties that are often seen as having divergent interests - the venue, or "originate" space of culture, and the developer, or "incoming actor" within the space. The key component here, and one that is in line with an equal recognition and valuation of different kinds of intangible cultural iterations, spaces, practices, and communities is that both parties must work together in order to equitably use the space at all periods of the day/night continuum (i.e., all hours). $f$

An example cited for its recent success in operationalizing the spirit of the agent of change principle is the case of the famous London music venue Ministry of Sound. Here, a deed of easement of noise was entered into by the developer, such that noise from the Ministry of Sound could legally pass over the new development without the new residents being able to lodge noise complaints pertaining to the legal noise "burden" on their property. ${ }^{83}$ The London's Mayor's Music Venue Taskforce and related Grassroots Music Venues Rescue Plan recounts:

A deed of easement of noise was entered into between the owner of Eileen House and Ministry. Its effect was to allow noise (at the nightclub's existing levels) from Ministry (known as the dominant tenement) to lawfully pass over the Eileen House development (known as the servient tenement). As Ministry now had a lawful right to make the noise at those levels, and for that noise to pass over the Eileen House site, its new residents couldn't then complain about the noise. In short, they would be buying their flats with that legal "burden" already imposed. The right was a proprietary right (i.e. a property right), and was no different in law to many other proprietary rights (e.g. rights of light, rights of support etc). However, no deed of easement of noise had ever been entered into before to the best of anyone's knowledge. In terms of its drafting, however, it was relatively straightforward, as the principles for the drafting of proprietary rights are well-established. The outcome was an excellent example of "good planning". The club was protected and the development could go ahead. Equitable neighbourly relations were established at the outset. In a crowded city, that is a laudable and much-required objective. ${ }^{84}$

In addition, when implementing something like the agent-of-change principle, the various spaces and parties within a space must also cooperate in the construction and acoustic design and assessment of a space. ${ }^{85}$ Not only is the noise-emitting venue no longer solely tasked with altering its business operations or noise emissions and

\footnotetext{
"Developers Required to Pay for Sound-Proofing Against Live Music Venues Under New Planning Principle", ABC News (4 August 2014), online: <www.abc.net.au>.

${ }^{83}$ London's Music Venues Taskforce, "Rescue Plan", supra note 69 at 46-47.

${ }^{84}$ Ibid at 47.

${ }^{85}$ Sean McArdle, Gillian Lee \& Elizabeth Hui, "Live Music and the 'Agent of Change' Principle” (Paper prepared for inter.noise 2014, the $43^{\text {rd }}$ International Congress on Noise Control Engineering, Nov 16-19, 2014, "Improving the World through Noise Control") at 6-7, available online:

$<$ www.acoustics.asn.au/conference_proceedings/INTERNOISE2014/papers/p792.pdf>.
} 
building soundproofing design (where this is both costly but also sometimes impossible if dealing with an older heritage building), but the surrounding parties must work with the space to effectively measure noise emissions at the most relevant times in order to arrive at the most accurate calculations needed for precise soundproofing design in the new development. ${ }^{86}$

Rather than the incoming space or associated developer measuring noise emissions without the knowledge of the noise emitting venue in question, the developer must work and liaise with the venue to ascertain times and levels of maximum noise emission and even test the volume levels of noise emission that are beyond usual levels in order to ensure even higher levels of potential noise insulation. ${ }^{87}$ In facilitating this collaborative neighbourhood equity and civic-engagement project through the agent-ofchange principle, cities such as London are addressing concerns about the increasing loss of intangible spaces of music and grassroots music culture.

\section{CONCLUSION}

Drawing on the notion of community subcultural wealth as one of the intangible cultural heritage attributes of a city, the protection of spaces where this attribute flourishes ensures the protection of the cultural and subcultural value of these city spaces against their exchange-value associated with city redevelopment projects. Where the goal of city governance and legal frameworks should be the equal treatment and valuation of its urban citizens, it is crucial that cultural and subcultural choices that do not neatly fit into dominant societal norms, conventional day/night use, and spatial occupation patterns do not fall into invisible cracks that lead to their undervaluation and inequitable treatment. Moreover, an equitable regard for multiple iterations of value would have the ancillary yet significant benefit of increasing the exchange-value associated with property (generally) within municipalities as a result of the city becoming (or remaining) a desirable place to live. Examining Toronto's Music City aspirations reveals the current legal and policy mechanisms through which the undervaluation and inequitable treatment of certain iterations of culture occurs. The various legal barriers subcultural music communities face in accessing and maintaining their spaces of community lead municipalities, like Toronto, to focus predominantly on the present exchange value of these city spaces, to the detriment of intangible cultural heritage. However, progressive policies such as the agent-of-change principle, and conscientious zoning practices that embody creative placekeeping objectives, among other policies, present a number of dynamic legal reform options available to municipalities to prevent the loss of these important sites in the future.

\footnotetext{
${ }^{86} \mathrm{Ibid}$ at 7.

${ }^{87}$ Ibid.
} 